\title{
US-CHINA RIVALRY FOR GLOBAL HEGEMONY
}

\author{
Valeri Modebadze \\ St. Andrew the First-Called Georgian University of the Patriarchate of Georgia, Georgia \\ ORCID iD: https://orcid.org/0000-0002-1232-4841 \\ valery_4@yahoo.com
}

\begin{abstract}
This article describes the competition between China and the USA for global hegemony. Both states have hegemonic ambitions and compete with each other over the domination of Asia. The rise of China has transformed global politics, as well as the balance of the global economy. As China's economic and military power increases steadily, its geopolitical ambitions are also constantly growing. Some experts do not exclude the possibility of conflict between China and the USA in the future. There are many potential hot spots in East Asia where conflict could erupt at any time in the future between the USA and China. Many experts doubt whether the USA and China can escape Thucydides' Trap in the future.
\end{abstract}

Keywords: Hegemony; Sino-American competition; Thucydides' Trap; Conflict; Domination; Asia; Rise of China

\section{INTRODUCTION: THE RISE OF CHINA}

In the 1990s, when China was weak, many scholars and experts used to raise a question about a possible rise of China. Most strategic debate about China focused on the issue whether or not China could become a peer competitor of the USA. This issue is outdated and irrelevant nowadays. The rise of China is now a fact. Its economy and military power is constantly growing and it is already competing with the USA in all spheres. The rise of China has transformed global politics, as well as the balance of global economy. We are entering now a world where the USA is no longer the only great power on the planet. We are moving out of the unipolar world to a multipolar world which will be dominated in the future by many great powers. The USA will remain the most powerful state in the international system for the foreseeable future, but it won't be the only superpower in the international 
system. The competition between the USA and China will be the defining factor in international politics. Most strategic debate about China now revolves around one question: How china will behave in the future as it rises and will USA be able to stop China's dominance of the world?

Two centuries ago Napoleon predicted the rise of China. Napoleon warned that the rise of China would shake the world. Once he stated: "Let China sleep, for when she wakes, she will shake the world" (Charles E. Boyle, 2004). Now we live in the era when China is beginning to wake up and the world is beginning to shake. China is the world's largest manufacturer and exporter and its economic power is constantly growing. China is now a major contributor to global economic growth. It is now the only plausible challenger to the USA. During the Cold war era, when China was weak, Beijing did not appear to have any expansionist goals. In the XXI century, as China's military and economic power grows, its appetite also increases. Some experts do not exclude the possibility of war between the USA and China in the future. For instance, Professor John Mearsheimer believe that war is inevitable between China and the USA. But he thinks that if the war will break out between these two biggest states, it will be a limited war and not a global war. Global war will not take place, because both states are nuclear powers and have the capacity to destroy the world (Valdai Club, 2016).

As China continues to rise, relationship between the USA and China deteriorates considerably. There are many reasons to believe that the relationship between these two biggest states will worsen in the future. In order to explain why China cannot rise peacefully, we should first understand how great powers behave in the anarchic international system.

\section{HOW GREAT POWERS BEHAVE IN THE ANARCHIC INTERNATIONAL SYSTEM?}

In his scientific article 'Anarchy and the Struggle for Power' John Mearsheimer explains how great powers behave in anarchic international system. According to him great powers fear each other and they do not trust each other. As he states: "There is a little room for trust among states. For sure, the level of fear varies across time and space, but it cannot be reduced to a trivial level. From the perspective of any one great power, all other great powers are potential enemies" (Mearsheimer 2001, 29-54). This anarchic international system forces great powers to act aggressively towards each other. The great powers are rarely satisfied with the status quo and seek hegemony. The great powers are power-maximizers and they want to increase their military and economic power as much as possible (Mearsheimer, 2007). Because of the absence of higher authority, states operate in self-help system and try to be as strong as possible in order to protect their national interests. The best way to survive in this anarchic international system is to be powerful. The great powers are never happy with the power distribution in the international system and try to change the balance of power in their favor. There is mistrust between great powers and they have hostile intentions towards each other. 
They have hegemonic ambitions and contradictory geopolitical interests. They compete fiercely with each other and whenever suitable condition arises they fight against each other in order to increase their power. In his book 'The Tragedy of Great Power Politics' Professor Mearsheimer explains that conflict between great powers is inevitable and will never see an end. Because hegemony is the best way to survive in the anarchic international system, the competition between great powers will never end (Mearsheimer, 2014). According to Mearsheimer, great powers have two strategic goals: First, they have to dominate the region, where they are located in, because they know that the best way to survive in the anarchic international system is to become a regional hegemon. Second, after achieving regional hegemony, the dominant state aims to prevent other states to rise and become its peer competitor (Centre for International Policy Studies uOttawa, 2012).

The ultimate goal of every major power is to be a dominant power in the region and then hopefully in the global system. According to Mearsheimer when the USA was in the process of establishing hegemony in the Western hemisphere, it did not have any peer competitors. But in the XX century there were 4 potential competitors: Imperial Germany, Imperial Japan, Nazi Germany and the USSR. So far, the USA managed to defeat all potential competitors: In the First World War, the USA played a crucial role in finishing Imperial Germany. In the Second World War, the USA destroyed Japan. It also played a key role in defeating Nazi Germany. During the Cold War the main competitor of the USA was Soviet Union. During the Cold War, Americans played a central role in containing the Soviet Union, which proved very effective strategy in the long run. Thanks to this policy of containment, the USA managed to get rid of its peer competitor, the Soviet Union. The USA does not tolerate peer competitors and is always glad to get rid of them. Shortly, after the Soviet Union disappeared, the Bush administration made it clear that the USA was number one state in the world and intended to stay in that way. But, the rise of China created a new headache for the USA and many have started to doubt whether or not it can remain number one state in the international system. China is now the only plausible challenger to the USA (Centre for International Policy Studies - Ottawa, 2012).

\section{THE ISSUES THAT CAN STRAIN RELATIONS BETWEEN THE USA AND CHINA IN THE FUTURE}

One might well ask, what issues can strain relationship between the USA and China in the future? What spark would likely provoke hostilities between the USA and China? Well, there are many problematic issues that can cause the escalation of conflict between these two great powers. According to Graham Allison, both states can fall into Thucydides' Trap and then, conflict between them will be inevitable. There are 3 main hotspots in East Asia: First hotspot is the South China Sea, second is Taiwan and third is East China Sea. Apart from these hotspots, the containment policy can also lead to escalation of conflict. Let's first examine the containment policy of China - John Mearsheimer's argument is that if China continues to grow economically over the next 30 years much the way it has over the past 30 
years, then it will translate that wealth into military might and it will try to dominate Asia the way USA dominates the Western Hemisphere. The USA will not tolerate any great power to dominate Asia. It is in the strategic interest of the USA to prevent China to become a regional hegemon. In order to achieve this goal the USA will form a balancing coalition in Asia which will include most of China's neighbors. China's neighbors are scared of China's rise and therefore, will join this balancing coalition. If China will turn into a giant Hong Kong, all of China's neighbors will be very nervous and they will unite their efforts in order to contain China and prevent it from dominating Asia. Balancing coalition will consist of the following states: South Korea, Japan, USA, Taiwan, Singapore, Vietnam, India and probably Russia. This will all lead to very intense security competition between the USA and China. (Mearsheimer 2012).

In order to carry out effective containment policy the USA will need to build large number of military bases in China's neighboring countries and has to deploy more troops in Asia pacific region. In the long run this containment policy will lead to the deterioration of relations between the USA and China and can cause the escalation of large scale conflict. In order to understand why the containment policy will lead to a conflict, we should explain a very familiar concept in international relations that is the concept of security dilemma. Security dilemma states that steps that one state takes to defend itself invariably appears offensive in nature to the other state.

The very good example of this is the containment policy. From the American perspective the containment policy is very defensively oriented strategy, the aim of which is to defend China's neighbors from Chinese aggression and contain China. From Chinese perspective, this policy does not look like containment, but it looks like encirclement of China. Therefore, Chinese government will be forced to increase country's military spending and military potential of the country in order to protect Chinese people from 'hostile' neighbors that try to encircle and isolate China. Because of the security dilemma, any measures that Chinese will take to defend themselves will automatically appear very offensive in nature from the American point of view. The states are fearful when other states develop military power because they don't know anything about their intentions. Because of unknown Chinese intentions, Americans will react and will do their best to have as much sophisticated weapons and arms as Chinese have. This could lead to arms race between the USA and China and the situation will resemble very much the cold war, when there was a fierce competition in the military sphere between the USA and the USSR. According to Mearsheimer it is necessary to slow down China's economic growth in order to avoid such a tragic scenario, because if China does not grow economically it cannot turn material wealth into military might and become a potential hegemon in Asia. China is becoming incredibly wealth country and the great fear is that China will turn into a giant Hong Kong. In this case it will become a formidable military power. China is already pouring enormous amount of money into its military with the clear aim of challenging American hegemony in the Pacific. China is developing and modernizing its military force and its strategic aim is to increase military 
potential as much as possible in order to be able to challenge the USA dominance in the Western Pacific. Conflict between China and USA seems inevitable because these two strongest states compete with each other over the domination of Asia.

Chinese economic and infrastructural projects such as the Belt and Road initiative is often viewed by Americans as Chinese attempt to challenge the USA primacy in Central Asia, Europe and other parts of the world. So, the question is, can Americans prevent China from becoming a giant Hong Kong?

President Trump's administration is doing everything it can to halt China's economic growth by imposing tariffs on Chinese products. This trade war is a manifestation of SinoAmerican competition for hegemony and the geopolitical rivalry. The USA will do everything it can to stop the rise of China. We are entering now a new era - The Sino-American Cold War.

James Fanell, former intelligence chief of the USA Pacific fleet challenges the conventional wisdom that the USA military is unsurpassed by any force on this planet. He thinks that there is a high possibility that the USA and China will go to war in the next 30 years. China is waiting for a right moment in order to regain control over Taiwan. James Fannel thinks that by 2035 China is very likely to attack Taiwan. Chinese military was ordered by $X_{i}$ Jinping to have the capability to take Taiwan by military force. China is building up its military capability in order to be able to confront the USA and regain Taiwan before 2049.

In 2049, the Chinese people celebrate the $100^{\text {th }}$ anniversary of the People's Republic of China and their aim is to invade Taiwan before that event. For this reason, Xi has carried out large-scale reforms in the Chinese military and started the modernization process of Chinese armed forces in order to be capable of achieving his long-term military objective. The Chinese believe that they already have capability to conquer Taiwan. Many experts doubt that they actually have that capability, but the problem is that this belief will get stronger over the next 10 years. Therefore, the challenge that USA is facing now is how to deter Beijing from deciding to use military force against Taiwan (Zooming in with Simone Gao, 2020). China has declared that it is not a status-quo power. It is in reality a revisionist power which is bent on changing the status-quo in Asia. Apart from Taiwan, the Chinese now have laid claims over are a group of small islands in the East China Sea.

The Chinese have disputes with Japanese over little islands known as Senkaku islands and think that they should become Chinese. Moreover, there is a huge dispute over who controls the South China Sea. China wants to dominate this strategic sea which is rich in natural resources and has a lot of oil and gas reserves. China is building artificial islands in the sea in order to establish a firm foothold in this strategic place. The borders are not demarcated between China and its neighboring countries and there is a very fierce competition between them to control strategic islands and various zones in the South China Sea. Apart from China, following countries lay claim over the islands in South China Sea: Brunei, Indonesia, Malaysia, the Philippines, Taiwan, and Vietnam. The territorial disputes between these countries are so complicated that it seems almost impossible to solve them by 
any legal means. China claims 90 percent of the sea, which creates enormous tensions between Beijing and countries of the South China Sea. Conflict can erupt any time in the future between these countries over disputed territories. Neighboring countries of China are weak and desperately need the USA military support to deter China from dominating strategic territories in South China Sea. Therefore, it is in the USA interests, as well as in the interests of the USA allies to increase American military presence in the South China Sea. If conflict will intensify in the South China Sea, then countries of South China may show an interest of joining a balancing coalition with the USA in order to stop the expansion of China and defend their national territories.

According to American Professor Graham Allison there is a high probability of conflict, when a rising power threatens to displace the ruling power. He developed a concept of Thucydides' Trap, which is now well known among scholars and experts. Ancient historian Thucydides explains well why conflict is inevitable when a rising great power challenges the dominance of the ruling power. According to him, it was the rise of Athens and the fear that this instilled in Sparta that made war inevitable between these two strongest states of the Greek World in the V century BC. In his book 'Destined for War' Allison explains why it is so difficult for great powers to escape Thucydides' Trap. He examined from history various cases of rivalry between great powers and came to the conclusion that from 16 cases of rivalry, 12 ended with open conflict (Graham Allison 2017). The Chinese President Xi is already familiar with the work of Graham Allison and thinks that all politicians should work together and make maximum efforts to avoid Thucydides' Trap.

\section{CONCLUSION}

As we have seen above there are many potential hotspots in the East Asia where conflict could erupt any time in the future between the USA and China. China is not a statusquo power and has great ambitions to dominate Asia. Of course, the USA will not tolerate this and will do everything it can in order to avoid the development of such scenario. For the USA it is unacceptable for any other great power to establish an exclusive hegemonic control over the Asia and the Western Pacific. Time will show us whether or not the USA and China will fall into Thucydides' Trap in the future. The next generations will see soon if Washington and Beijing will follow in the tragic footsteps of Athens and Sparta. If conflict will take place in the future between these two strongest states, even if it will be limited in nature, it will inflict enormous damage on international trade and global economics. 


\section{REFERENCES}

1. Boyle, Charles E. 2004. "China Wakes Up as the World Watches." Insurance Journal West, https://www.insurancejournal.com/magazines/mag-features/2004/07/19/44587.htm

2. "John Mearsheimer Discusses Global Order and Great Power Politics at Valdai Club." YouTube video, 1:29:56, "Valdai Club", October 20, 2016, https://www.youtube.com/watch?v=Z6k1XorBiZY

3. Mearsheimer, J. J. (2001). "Anarchy and the struggle for power". In: The tragedy of great power politics. New York and London: W W Norton \& Company. pp 29-54.

4. Mearsheimer, J. J. 2014. The Tragedy of Great Power Politics. New York: W. W. Norton \& Company.

5. "Why China Cannot Rise Peacefully". YouTube video, 1:30:45, "Centre for International Policy Studies uOttawa," October 26, 2012, https://m.youtube.com/watch?v=CXov7MkgPB4

6. "U.S. and China will likely go to war in the next 30 years." YouTube video, 4:23, " Zooming in with Simone Gao," January 19, 2020, https://m.youtube.com/watch?v=sMyoCIAO9YO

7. Allison, Graham. 2017. Destined for War: Can America and China Escape Thucydides's Trap? New York: Houghton Mifflin Harcourt. 